\title{
The Impact of Emotional Intelligence on Loan Officers' Intermediate Judgments
}

\author{
Bruce Lagrange, Chantal Viger, and Estelle M. Morin
}

\begin{abstract}
This study follows up on by examining whether emotional intelligence (EI) has a moderating effect on loan officers' intermediate judgments. In view of findings of that EI does not affect loan officers' main judgments, these being circumscribed by the standards of their institution, we look at the potential impact of loan officers' EI on their intermediate judgments, which are not subject to such influence. In an experimental investigation, participants' judgments and decisions are examined in light of three methods of disclosing contingencies. Their intermediate judgments are considered to pertain to the borrower's overall financial condition, profitability potential, ability to pay debts and ability to sustain growth. Results show that the impact of EI as a moderating variable in the relationship between the method of disclosure and intermediate judgments, and between these judgments and the loan granting or interest rate decision, does not establish that loan officers' EI has a significant moderating effect, except between two intermediate judgments (profitability potential and ability to sustain growth) and the loan granting decision, for which results were marginally significant.
\end{abstract}

Index Terms-Decision process, emotional intelligence, intermediate judgments, IAS 37, loan officers.

\section{INTRODUCTION}

The current study follows up on a study by [1] on the potential moderating effect of loan officers' EI on the judgments and decisions they make subsequent to their analysis of accounting contingencies within the context of a loan decision. Reference [1] concluded that loan officers' EI did not have a significant moderating effect on these judgments and decisions. North American financial institutions generally require loan officers to study the overall risk rating (ORR) and overall trend rating (OTR) before making a decision on whether to grant or deny a loan [2]. These variables, styled as ORR and OTR, constitute the two main judgments in this decision process. Reference [1] show that loan officers use a fairly standardized decision process. In addition, the authors' use of EI as a moderating variable in the relationship between the method of disclosing contingencies and ORR or OTR judgments, and between these judgments and loan granting or interest rate decisions, did not establish that loan officers' EI has a significant moderating effect on these relationships. This may be because institutional oversight and directives are sufficiently clear and accurate, providing guidance and

\footnotetext{
Manuscript received November 20, 2018; revised January 18, 2019.

Bruce Lagrange and Chantal Viger are with Université du Québec à Rimouski, Canada (e-mail: bruce_lagrange@uqar.ca, viger.chantal@uqam.ca).

Estelle M. Morin is with HEC Montréal, Canada (e-mail: estelle.morin@hec.ca).
}

minimizing loan officers' personal differences in terms of EI. As a follow-up to this study, we examine the potential impact of loan officers' EI on other judgments not specifically influenced by institutional policies and standards, which we call intermediate judgments.

Some psychology studies have concluded that emotions can influence the judgments and decisions of individuals, and that emotional regulation can play a role in financial decision making. The research to date shows that individuals who more easily identify the emotions that convey information on a situation and context, and who can manage emotions with potentially disorganizing effects, are better placed to respond to the adaptation requirements of the external environment, such as decision making.

Our objective is to determine whether emotional intelligence (EI) acts as a moderating variable in loan officers' information processing, and whether it moderates risk perception and credit-granting decisions. Our research question is the following: Does loan officers' EI moderate their intermediate judgments and decisions when they analyze information on accounting contingencies? To answer this query, we conducted an experimental study similar to [1] to analyze respondents' judgments and decisions further to the administration of questionnaires pertaining to three methods of disclosing contingencies in regard to a Canadian firm. The recognition and disclosure methods are those prescribed by three standards for accounting for provisions: 1) the Canadian Section 3290 standard; 2) IAS (International Accounting Standard) 37, in effect since $2011 ; 3$ ) the international standard proposed in the Exposure Draft of Proposed Amendments to IAS 37. Each experimental group was assigned a disclosure method in the foregoing order (G1, G2 and G3 respectively). The results obtained are mixed but none is very significant. Whether in the relationship between disclosure of contingencies and loan officers' intermediate judgments, or between loan officers' intermediate judgments and decisions, the results do not indicate that loan officers' EI has a significant moderating effect on these relationships, except the relationships between two intermediate judgments (profitability potential and ability to sustain growth) and the loan granting decision. The following section presents the theoretical framework and the motivation behind the study.

\section{BACKGROUND AND MOTIVATION}

Loan officers are an important group of professional financial statement users because they perform a significant role in providing capital to businesses. In fact, debt accounts for more than fifty percent of SMEs' capital [3]. Bank loans 
are the primary source of financing for these types of organizations [4]. In recent decades, market globalization, escalating competition in business, financial and organizational environments, and rapid economic, social and technological change have contributed to growing uncertainty and instability in financial and business environments and have compounded the complexity of financial decisions [5].

All of the above changes impact on the risk management activities of financial institutions. Depth of analysis and risk management depend on loan officers' diligence and conscientiousness, both of which can be influenced by their intrinsic characteristics. Although loan officers use standardized tools and follow an analysis process guided by their institutions' standards and credit lending practices, their decisions may be influenced by their individuality and biases [6].

The greater complexity of loan officers' decision process makes the process of approving or refusing a loan more difficult, especially when it involves a new client. In such cases, the information asymmetry between the loan officer and the borrower may be considerable and can lead to concealment of crucial information [7]. According to [8], the decision process involves more than the application of the institution's standards and procedures; it also requires significant knowledge, skills, and personal qualities. In addition to cognitive and rational aspects of knowledge, the ideal loan officer should possess specific personal, conative and personality traits. Personal traits include sales talent, networking ability, business acumen, interpersonal communication, and negotiation skills; action, client and results orientation; independence and problem solving; and the ability to make quality decisions at the right time [9]. In light of the foregoing, it is relevant to study loan officers' decision process and the factors that can help improve the quality of their decisions.

The issue of the influence of disclosure in the financial statement notes versus the income statement and balance sheet has been the subject of experimental research [10][18]. All these articles arrive at the same conclusion: that the characteristics of information disclosure (whether in the notes or in the financial statements) significantly affect the perceptions and decisions of financial statement users. Among the studies conducted to understand this influence, reference [11] concluded that characteristics of financial information disclosure can influence the judgments and decisions of professional financial statement users as a result of functional fixation, regardless of users' level of sophistication. According to functional fixation, locating information in the income statement vs. the notes can lead to different judgments and decisions. Users are sometimes inclined to retain the interpretation of net income that they obtained after reading the income statement and before they acquired the information disclosed in the notes [19].

The types of decisions made by loan officers and the setting in which they operate undoubtedly trigger emotions in these actors that can range from extremely positive to extremely negative and from weak to highly intense. Financial decision making, especially when a credit application is involved, constitutes a situation in which information is often difficult to acquire. It also presents highly uncertain circumstances for decision making. As a result, negative emotions such as anxiety may run high. In fact, situations that present new conditions or uncertainty produce anxiety, an emotion that signals risk or the possibility of harm and that invites a response aimed at reducing risk and protecting the interests at stake. Therefore, an anxious person tends to focus on negative information rather than on neutral or positive information [20]. Reference [21] observed that rigid attitudes generated by anxiety hinder comprehension of the problem, and consequently, the formulation of a solution.

The main motivation behind the current research is the conclusion reached by [1] and the relevant psychology literature, setting forth the notion that emotions and their management can influence decision making. As loan officers' main judgments (ORR and OTR) are usually formulated with institutional policies and standards in mind, we turn to the study of their intermediate judgments. To make a main judgment about overall risk and the overall risk trend, a loan officer must first reflect and form an opinion about several factors, such as the enterprise's overall situation, including its financial situation, profitability, and growth potential. Although institutional policies provide a framework for making the main judgments (ORR and OTR), no guidance or structure is given for analyzing these other factors, leaving loan officers with much more latitude to form their own opinions. Given this relative absence of institutional influence, it appears relevant to study the moderating impact of a personal attribute like EI on loan officers' intermediate judgments.

\section{LITERATURE REVIEW}

Since this study follows the same theoretical framework as [1], this section sums up and updates their literature review in light of the new topic of intermediate judgments.

\section{A. The Role of Emotions in Decision Making}

Traditional economic decision-making models are based on the classic rationality hypothesis that assumes that rationality is objective and impartial. The models also suppose that the beliefs and choices of economic agents follow rational principles to maximize their anticipated utility [22]. This perspective also assumes that decision makers have a perfect knowledge of all the options and their consequences, and can thus make the optimal choice. This postulate was questioned by [23], who claimed that the rationality of decisions is bounded by the environment's influence on the decision maker, the biases inherent in the decision maker's personality, and the decision maker's experience and personal goals. Concerning personal biases, equal attention must be paid to the limits of the decision maker's perceptual and reasoning capacities and of his or her ability to interact with the surrounding world and adjust to circumstances.

Two further constraints greatly hinder decision quality. The first constraint is uncertainty, while the second is the complexity of the problem that must be solved. With this in mind, decision makers would not be inclined to search for the optimal solution among all the possible options, because of lack of time, information, or ability. Rather, they would 
come to a decision as a result of a desire for satisfaction rather than maximization [24]. Although they may demonstrate logic during the reasoning process, the final decision is limited by their ability to sense, perceive, and recognize relevant information and by the values and interests that drive their decisions and actions.

According to [25], investors, executives, managers, and other economic agents are not rational examples of homo economicus who behave as predicted in mathematical models. They are men and women endowed with intelligence, experience, and reasoning skills who do their best to make optimal decisions. The quality of these decisions improves to the extent that decision makers learn to master the biases inherent in their reasoning process and problem solving, especially by regulating their emotional biases [26].

Further, the neurologist Antonio Damasio argued that emotions actually lend rationality to our decisions. Evidently, when emotions run too high, they can lead to unreasonable reactions - thus the importance of knowing how to regulate them. In fact, by trying to understand one of his patients, whom he called Elliot, reference [27] discovered the role that emotions play in decision making. Before his brain surgery, Elliot was a businessman who had become successful as a result of his investment decisions. After his convalescence, he was unable to value investment projects despite still knowing how to read financial statements. Reference [27] concluded that Elliot's ability to assess a situation and make a decision had been affected by an emotional deficit.

Emotions are important guides for judgments, reasoning, and decision making. Each cognitive process, including attention, judgment, assessment of probabilities, and risk perception is systematically and profoundly influenced by emotions [28]. Each emotion is accompanied by its own lens, through which actors see and construct their representations of the world around them [20]. Our perception of an item is informed by how sensory images resonate with our knowledge of that item. Consider the example of a loan officer who sees financial statements on his desk (perceived object). As soon as he becomes aware of them, a visual image forms, along with an association with the knowledge he has acquired about this item. The loan officer will formulate his representations based not only on this knowledge, but also on his affective state at the time he examines the data in the report. If he is in a positive state, his assessment will most likely be positive, whereas it will be negative in a negative state [29].

\section{B. Emotional Intelligence (EI)}

In line with [1], we borrow from [30], who concluded that EI is relevant to the study of emotions because individuals who are aware of and can regulate their emotions, and who understand their emotions as well as those of others, are generally happier and more successful in their endeavors. We focus on the EI personality trait, based on the model of [30]. Trait EI defines EI as a constellation of emotionrelated dispositions capturing the extent to which individuals identify, understand, regulate, and utilize their own emotions and those of others [31].

Emotional intelligence is the ability to learn and to reason using the information provided by emotions to facilitate adaptation. The ability to recognize emotions and understand their meaning better places individuals to improve decision performance. This is because they have at their disposal critical information about the situation and their environment and are capable of managing emotions that can have disorganizing effects.

Decision quality increases with the ability to obtain and analyze the most relevant information. Reference [32] found that higher EI makes a person better at searching for information, regardless of personal stress level. Lower information search skills can lead to the neglect of factors relevant to the decision-making process and thus to poor decisions [33].

Reference [34] demonstrated that individuals with higher EI are less influenced by cognitive biases, a situation that increases their decision efficiency. Reference [35] found that decision makers with such skills answered more questions correctly, indicating that they are less influenced by emotional cues, which further equips them to make a decision.

Decision studies mainly dealing with finance also found that decision quality is linked to the decision makers' IE. Some studies highlighted that emotions influence several types of judgments, including risk assessment [36], [37]. Reference [38] observed that investors who display more intense emotions perform better. Referring to neuroeconomic research, reference [39] indicates that emotions can influence financial decisions. One such study, conducted by [40], demonstrated that participants who viewed an image associated with a negative emotion made less risky investment decisions than those who viewed a neutral image.

Emotions have long been considered a disorganizing factor unsuited to guiding decisions, especially when associated with forms that appear to have a more organizing effect, such as reasoning principles [41]. However, based on the previous paragraphs, we posit that emotions allow individuals to classify information in order of importance because they in fact serve to assess the relevance of information from among a multitude of stimuli, supporting the cognitive process in its navigation of a complex and unpredictable environment [42]. According to [43], individuals who are aware of their emotional state can be fully rational in their decision process given their ability to decide which action to take in view of their emotions.

\section{HYPOTHESES}

Fig. 1 models loan officers' decision process and the relationships between independent and dependent variables, while considering EI as the moderating variable. According to this model, level of information disclosure influences loan officers' intermediate judgments, which in turn influence their decision about granting the loan and determining the interest rate. The model captures the effect of moderating variable EI on these relationships.

Reference [1] did not demonstrate that loan officers' EI has a significant moderating effect on the relationship between the method for disclosing contingencies and ORR or OTR judgments, or between these judgments and loan granting or interest rate decisions. Their results suggest that 
loan officers functionally fixate on net income based on the fact that participants in one of the experimental groups, in the course of formulating their judgments and decisions, did not appear to have considered information given in the complementary note, which would have allowed them to reconcile their net income figure with that given to the other groups. Contrary to the authors' expectations, participants with higher EI were unable to overcome the effects of this functional fixation.

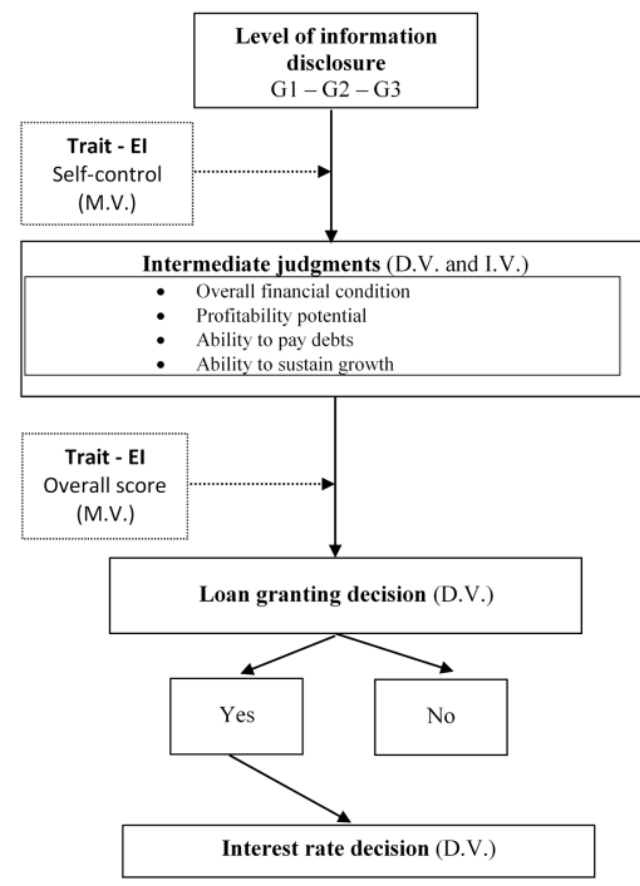

Fig. 1. Decision-making model.

G1: Measurement and presentation according to the Canadian Section 3290 standard

G2: Measurement and presentation according to IAS 37

G3: Measurement and presentation according to the exposure draft of proposed amendments to IAS 37

I.V.: Independent variable

D.V.: Dependent variable

M.V.: Moderating variable

Reference [1] explained these results by the fact that institutional oversight and directives were sufficiently clear and accurate in the case they used, and that guidance was thus provided to the extent that it minimized the effect of loan officers' personal EI differences. Considering the low variability observed in the determination of judgments relative to risk and the presence of this institutional guidance on judgments and decisions, reference [1] indicated the need to delve further into the impact of EI on intermediate judgments. These judgments, which are not specifically addressed by institutional practices, pertain to the firm's overall financial condition (CONDITION) and profit potential (PROFIT), ability to pay off debts (DEBT), and growth prospects (GROWTH).

The goal of the current study is thus to examine whether loan officers' EI moderates the relationship between the method for disclosing contingencies and loan officers' intermediate judgments (CONDITION, PROFIT, DEBT and GROWTH) and the relationship between their intermediate judgments and decisions (LOAN and RATE). In view of the method for disclosing contingencies assigned to each experimental group, we expect that participants assigned to G3 would predict higher future net revenues and a more positive capital structure than those assigned to G1 and G2 (since G3 had a lower expense related to contingent liabilities), and that this prediction would contribute to more favorable judgments and decisions by G3 than by G1 and G2. These expectations are based on the results of a number of studies, including [11], which confirmed the anticipated effect of functional fixation, even on professional financial statement users. According to functional fixation, the choice of presenting the information by recognizing it in earnings or disclosing it through a footnote can lead to different judgments and decisions, given that information disclosed in a footnote is not taken into account by users who hold on to their interpretation of net income based on the income statement, which they acquired before reading the footnote information [19].

Financial decision making following an application for financing creates a scenario in which information is difficult to acquire and the decision-making process is often fraught with uncertainty; as a result, negative emotions can come to the fore. According to [44], those who make the best of the situation understand the meaning of their emotions enough to adapt effectively. However, loan officers with low EI resort to defensive strategies by protecting themselves through functional fixation, which allows them to remain in their comfort zone and hold on to their interpretation of information considered to be reassuring and conventional. Conversely, loan officers with higher EI count on their ability to identify, understand, manage, and use their emotions and those of others, and are thereby able to formulate the best judgments by mitigating, to the extent possible, the disorganizing effects triggered by some emotions. We therefore expect that the functional fixation predicted for participants could be moderated in loan officers with higher EI. Thus, notwithstanding the expectation that G3 participants would be more favorable in their judgments and expectations than those in G1 and G2, these judgments and decisions are expected to be less favorable as EI increases.

Hence, our first four hypotheses center on the moderating effect of loan officers' EI on the relationship between the contingencies disclosure method and judgments about the firm's overall financial condition (CONDITION) and its profit potential (PROFIT), capacity to pay off its debts (DEBT) and growth prospects (GROWTH). EI represents facets related to self-control, i.e. perception and management of emotions, and stress management, and is measured by the TEIque, presented in the upcoming methodology section.

H1: The impact on CONDITION judgment, based on the method used to disclose information on contingencies, varies by EI level, as measured by the TEIque.

H2: The impact on PROFIT judgment, based on the method used to disclose information on contingencies, varies by EI level, as measured by the TEIque.

H3: The impact on DEBT judgment, based on the method used to disclose information on contingencies, varies by EI level, as measured by the TEIque. 
H4: The impact on GROWTH judgment, based on the method used to disclose information on contingencies, varies by EI level, as measured by the TEIque.

We next investigate whether a loan officer, having made a judgment, incorporates it in a coherent manner in the loan granting decision and determination of the interest rate. Lack of consistency with prior decisions and judgments could be moderated by loan officers' superior ability in the areas listed as the factors and facets of EI model of [30]. This part of the decision process is highly critical since loan officers must put their judgments into action via loan granting and interest rate decisions, which they must then communicate to all stakeholders. This situation could expose loan officers to various emotions brought on by institutional requirements (credit director's approval, expectations of the local institution's executive director) and dealing with borrowers' expectations and their own interests given their decision's potential impact on their salary, job security, and well-being in the workplace. These scenarios require implementing the facets and factors of emotional sensitivity (perception of others' emotions, relationship skills, and empathy) and sociability (social competence, management of others' emotions, and assertiveness).

For the following eight hypotheses on decision making, we expect that the decisions of participants with high EI (measured by overall score) would be more consistent with their prior judgments than those of participants with a lower level of EI. The hypotheses are the following:

H5: The CONDITION judgment's impact on the loan granting decision varies by EI level, as measured by the TEIque.

H6: The PROFIT judgment's impact on the loan granting decision varies by EI level, as measured by the TEIque.

H7: The DEBT judgment's impact on the loan granting decision varies by EI level, as measured by the TEIque.

H8: The GROWTH judgment's impact on the loan granting decision varies by EI level, as measured by the TEIque.

H9: The CONDITION judgment's impact on the interest rate decision varies by EI level, as measured by the TEIque.

H10: The PROFIT judgment's impact on the interest rate decision varies by EI level, as measured by the TEIque.

H11: The DEBT judgment's impact on the interest rate decision varies by EI level, as measured by the TEIque.

H12: The GROWTH judgment's impact on the interest rate decision varies by EI level, as measured by the TEIque.

\section{METHODOLOGY}

\section{A. Sample}

We examined bank loan officers working at a large financial institution in the province of Quebec, Canada. We obtained a relatively large response rate of 49 percent of our subjects. Almost 70 percent $(120 / 176)$ of those who participated in the study had at least an undergraduate degree, while 10 percent (18/176) and 22 percent (38/176) held a master's or a doctorate degree respectively. Thirtythree percent (58/176) had 15 years of experience or more, while 19 percent $(34 / 176)$ had 10 to 14 years, 18 percent (31/176), five to nine years, and 30 percent (53/176), less than five years. Sixty-three percent (108/170) of the respondents had personal lending authority under $\$ 150,000$; 18 percent (29/170) had between $\$ 150,000$ and $\$ 225,000$, and 19 percent $(33 / 170)$, over $\$ 225,000$. Eighty-nine percent $(156 / 175)$ had a professional certification, 69 percent $(120 / 175)$ were not confined to one area of specialty, and 57 percent (100/175) were male.

\section{B. Measure of Emotional Intelligence}

Trait El was measured through the French version of the Trait Emotional Intelligence Questionnaire (TEIQue) [30]; French adaptation by [45]. We used the short version (TEIQue-SF). This version comprises 30 items rated on a seven-point scale (strongly agree to strongly disagree). Previous studies have argued in favor of its reliability, validity, and usefulness [46]-[48]. The short version was used here on account of time constraints. It assesses 15 subscales and provides a global trait El score as well as scores on four specific factors (well-being, self-control, emotionality, and sociability). We chose the TEIQue to measure trait El for three specific reasons: first, it provides comprehensive coverage of the trait El sampling domain; second, its psychometric properties are excellent and its four-factor structure shows practical identity across languages [45]; and third, it has demonstrated discriminant validity in relation to personality and could be isolated in both Big Five and Giant Three personality factor spaces [49].

The scores obtained for EI level were classified into three groups (low, mid, and high) according to their percentile ranks. For each question, participants were asked to indicate their response on a 7-point Likert scale, 1 being Strongly Disagree and 7, Strongly Agree. For interpretation purposes, results were calculated out of a total of 10 . Regarding the self-control factor, out of a total of 10, 54 participants constitute the low group with an average of 5.83 (standard deviation $=1.07)$, 46, the mid group, with an average of 7.48 (standard deviation $=0.31$ ), and 71 , the high group, with an average of 8.62 (standard deviation $=0.51$ ). The overall average of three groups is 7.43 (standard deviation $=$ 1.37). Regarding the overall score, out of a total of 10,53 participants make up the low group, with an average of 7.13 (standard deviation $=0.54), 56$, the mid group, with an average of 8.01 (standard deviation $=0.17$ ), and 55, the high group, with an average of 8.73 (standard deviation $=0.30$ ). The overall average for the three groups is 8.33 (standard deviation $=0.75)$. Although the EI measure has good consistency, the EI scores demonstrated low variability after classification into three groups (low, mid, and high). When scores between subjects do not vary widely or sufficiently, we might expect difficulties observing their differences, in this case, based on low and high EI score.

\section{Procedure}

We used an experimental case similar to [1]. All the loan officers in the sample received descriptive information on a hypothetical company, along with a standard auditor's 
report and a complete set of financial statements and other relevant information relative to a loan application. The loan officers were asked to review the documents, perform a financial analysis, and make a decision about a loan request. As shown in Table I, the sample was categorized into three groups.

The first group received statements that followed the Canadian standards by recording the liability based on a reasonable estimate of the amount most likely to be paid, but without presenting it separately from other liabilities or disclosing any probability of the contingency occurring. The other two groups were given information that followed current and proposed IAS 37 by disclosing the contingency event's probability and presenting the contingent liability separately. The difference between current IAS 37 and the exposure draft is in the recording method. However, even if net income is different under the IAS 37 exposure draft versus the current IAS 37, the information provided in the note according to the IAS 37 exposure draft allows for the reconciliation of net income disclosed according to IAS 37. Thus, the information is available but is located in a different place. Any differences between the three types of disclosures should be due to the reporting and disclosure methods.

\begin{tabular}{|c|c|c|c|c|}
\hline & \multicolumn{4}{|l|}{ Experimental Groups } \\
\hline & Group 1 (G1) & Group $2(\mathrm{G} 2)$ & \multicolumn{2}{|c|}{ Group 3 (G3) } \\
\hline Experimental material & \multicolumn{4}{|c|}{$\begin{array}{l}\text { Each participant received an experimental package that included descriptive information on ABC Inc., a standard auditor's } \\
\text { report, and a complete set of financial statements for two fiscal periods (including all financial statements and } \\
\text { accompanying notes and main financial ratios). }\end{array}$} \\
\hline \multirow{2}{*}{$\begin{array}{l}\text { Financial statement } \\
\text { presentation format, } \\
\text { especially in regard to } \\
\text { contingent liabilities }\end{array}$} & CICA Handbook & $\begin{array}{l}\text { IFRS in effect since January 1, } 2011 \text { (IAS } \\
37 \text { ) }\end{array}$ & \multicolumn{2}{|c|}{ IASB's IAS 37 exposure draft } \\
\hline & $\begin{array}{l}\text { A contingent liability must be } \\
\text { recorded if 1) it is probable that an } \\
\text { event causing a loss will occur, and } \\
\text { 2) the amount of the contingent } \\
\text { loss can be appraised with a degree } \\
\text { of certainty. The amount to be } \\
\text { recorded should be based on a } \\
\text { reasonable estimate of the amount } \\
\text { most likely to be paid. }\end{array}$ & $\begin{array}{l}\text { Contingent losses are recorded as liabilities } \\
\text { when the likelihood of such losses is } \\
\text { greater than fifty percent, among other } \\
\text { conditions. The most likely amount } \\
\text { necessary for settling the obligation at the } \\
\text { closing date must be recorded. }\end{array}$ & \multicolumn{2}{|c|}{$\begin{array}{l}\text { Contingent losses are recorded as } \\
\text { liabilities when the elements meet the } \\
\text { definition of a liability, irrespective of } \\
\text { the probability. } \\
\text { The measurement would be the amount } \\
\text { that the entity would rationally pay at } \\
\text { the measurement date to be relieved of } \\
\text { the liability. }\end{array}$} \\
\hline $\begin{array}{l}\text { Disclosure of the } \\
\text { probability of occurrence }\end{array}$ & No & \multicolumn{3}{|c|}{ Yes. A $70 \%$ probability of occurrence is disclosed in both G2 and G3. } \\
\hline $\begin{array}{l}\text { Separate liability regarding } \\
\text { the lawsuit }\end{array}$ & No & \multicolumn{3}{|c|}{$\begin{array}{l}\text { Yes. The information available concerning the measurement of the provision expense } \\
\text { for the dispute is the same for experimental groups } 2 \text { and } 3 \text {. }\end{array}$} \\
\hline $\begin{array}{l}\text { Recent results and main } \\
\text { ratios }\end{array}$ & 2010 & 2009 & 2010 & 2009 \\
\hline - Net income & $\$ 104,747$ & $\$ 149,448$ & $\$ 200,355$ & $\$ 149,448$ \\
\hline - Increase in revenue $(\%)$ & $18.11 \%$ & $14.57 \%$ & $18.11 \%$ & $14.57 \%$ \\
\hline - Working capital ratio & 1.93 & 2.53 & 2.34 & 2.53 \\
\hline - Gross profit margin & $2.18 \%$ & $3.68 \%$ & $4.17 \%$ & $3.68 \%$ \\
\hline $\begin{array}{l}\text { - Return on shareholders' } \\
\text { equity }\end{array}$ & $14.18 \%$ & $23.46 \%$ & $23.97 \%$ & $23.46 \%$ \\
\hline - Earnings per share & $\$ 0.70$ & $\$ 0.99$ & $\$ 1.34$ & $\$ 0.99$ \\
\hline $\begin{array}{l}\text { - Capitalization ratio } \\
\text { (Equity/asset) }\end{array}$ & $48.81 \%$ & $56.34 \%$ & $55.95 \%$ & $56.34 \%$ \\
\hline - Dividends/share & $\$ 0$ & $\$ 0.17$ & $0 \%$ & $\$ 0.17$ \\
\hline - Cash flows & \multicolumn{4}{|c|}{ Cash flows from operating activities and total cash flows are identical for the three experimental groups. } \\
\hline
\end{tabular}

\section{DISCUSSION OF RESULTS}

\section{A. Preliminary Checks}

We examined the demographic characteristics of the subjects randomly assigned to each group. The demographic characteristics tested in regard to educational background, level of experience, personal lending authority, professional title, area of specialization, and gender were not significant.

Second, we used manipulation checks to ensure the loan officers understood the information presented to them. The manipulation checks included asking questions about the probability of the contingent liabilities being paid and whether contingent liabilities would be paid separately. In order to check whether the participants had actually perused the income statements, the participants were asked the extent to which net income had varied between 2009 and
2010. Those who failed the manipulation check were eliminated.

The third manipulation check was to test for non-response bias. No significant difference was found between early and late respondents for all demographic variables (using both full and reduced samples).

The fourth and last check was to test whether the experimental groups were equivalent in terms of loan officers' EI level and emotional disposition. Control variables were the facets of the first factor (well-being) in model of [30], consisting of traits related to disposition and behavior, i.e., happiness, self-esteem, and optimism. These scales are used to assess the individuals' affective state.

Table II, Panel A indicates that G1 participants scored an average of 8.83 on the EI well-being factor out of a total of 10 (standard deviation $=0.99$ ), while G2 scored an average 
of 8.72 (standard deviation $=1.05)$, and G3, 8.95 (standard deviation $=0.87$ ). ANOVA results show no significant differences between the three experimental groups in terms of this factor $(p=0.429)$. Thus, the participants in each experimental group did not differ from those in other experimental groups in terms of emotional disposition. The results of this study were not influenced by variations within this EI variable.

Table II, Panel B presents the results of the ANOVA conducted to ascertain nonresponse bias between the two respondent cohorts (before/after follow-up). The goal was to check if participants' emotional dispositions varied between both cohorts. Results indicate no statistical difference between the cohorts in terms of EI levels measured by the well-being factor $(\mathrm{p}=0.334)$.

\section{B. Test Results for Hypotheses}

Concerning the CONDITION judgment, loan officers with low EI awarded an average rating of 6.81 (standard deviation $=1.07$ ), while those with mid and high EI gave average ratings of 6.85 (standard deviation $=1.17$ ) and 7.04 ( standard deviation $=1.15)$ respectively. ANOVA results (Table III, Panel A) indicate no significant differences in a comparison of the three groups $(p=0.626)$. Thus, EI level does not affect CONDITION judgments. Based on the F-test (Table III, Panel B), we cannot conclude that an interaction effect exists; in other words, EI level has no effect on CONDITION judgment regardless of the method used to disclose the information $(\mathrm{p}=0.457)$. Hence, the impact of the method for disclosing contingencies on judgments about CONDITION is not influenced by loan officers' EI level. $\mathrm{H} 1$ is therefore not supported.

TABLE II: EMOtIONAL INTELLIGENCE: PARTICIPANTS' PROFILE AND TEST FOR NON-RESPONSE BiAS

\begin{tabular}{|c|c|c|c|c|c|c|}
\hline Panel A & Group & $\mathrm{N}$ & Mean & Std Dev. & $\mathrm{F}$ & p-value \\
\hline Level of Emotional Intelligence & & & $/ 10$ & & & \\
\hline \multirow[t]{5}{*}{ Factor: Well-being } & 1 & 56 & 8.83 & 0.99 & \multirow{4}{*}{0.851} & \multirow{4}{*}{0.429} \\
\hline & 2 & 56 & 8.72 & 1.05 & & \\
\hline & 3 & 61 & 8.95 & 0.87 & & \\
\hline & Total & 173 & 8.84 & 0.97 & & \\
\hline & \multicolumn{6}{|c|}{ Levene statistic for homogeneity of variance $=0.694(\mathrm{p}$-value $=0.501)$} \\
\hline Panel B & & $\mathrm{N}$ & Mean & Std Dev. & $\mathrm{t}$ & p-value \\
\hline Level of Emotional Intelligence & & & & & & (two-way) \\
\hline \multirow[t]{4}{*}{ Factor: Well-being } & Early $^{1}$ & 123 & 8.79 & 0.95 & \multirow{4}{*}{-0.969} & \multirow{3}{*}{0.334} \\
\hline & & & & & & \\
\hline & Late $^{2}$ & 50 & 8.95 & 1.02 & & \\
\hline & \multicolumn{5}{|c|}{ Levene statistic for homogeneity of variance $=0.357(\mathrm{p}$-value $=0.551)$} & \\
\hline
\end{tabular}

TABLE III: IMPACT OF THE CHARACTERISTICS OF INFORMATION DISCLOSURE ON OVERALL FINANCIAL CONDITION JUDGMENT USING THE EI MODERATING VARIABLE

\begin{tabular}{|c|c|c|c|c|c|}
\hline Panel A: Impact of EI Level on Overall Financial Condition & EI Level $^{1}$ & $\mathrm{~N}$ & Mean & Std Dev. & $\begin{array}{l}\text { F } \\
\text { (p-value) }\end{array}$ \\
\hline (CONDITION) & Low & 54 & 6.81 & 1.07 & \\
\hline & Mid & 46 & 6.85 & 1.17 & 0.469 \\
\hline I believe ABC's overall financial condition is & High & 71 & 7.04 & 1.15 & $(0.626)$ \\
\hline _. (on a 10-point Likert scale where 1 & Total & 171 & 6.92 & 1.13 & \\
\hline
\end{tabular}

indicates very poor and 10 indicates very good)

Levene statistic for homogeneity of variance $=0.294(\mathrm{p}$-value $=0.746)$

\begin{tabular}{|c|c|c|c|c|c|}
\hline Panel B: Overall Financial Condition (CONDITION) & $\begin{array}{l}\text { Group and } \\
\text { EI level }^{1}\end{array}$ & $\mathrm{~N}$ & Mean & Std Dev. & $\begin{array}{l}\text { F } \\
\text { (p-value) }\end{array}$ \\
\hline \multirow{3}{*}{$\begin{array}{l}\text { Interaction Effect Between Group (1,2 or } 3) \text { and EI Level } \\
\text { (low, mid or high) }\end{array}$} & 1-Low EI & 18 & 6.17 & 1.10 & \\
\hline & 1-Mid EI & 18 & 6.61 & 1.33 & 0.915 \\
\hline & 1-High EI & 20 & 6.85 & 1.09 & $(0.457)$ \\
\hline \multirow{11}{*}{$\begin{array}{l}\text { I believe } \mathrm{ABC} \text { 's overall financial condition is } \\
\text { (on a 10-point Likert scale where } 1 \text { indicates very poor and } \\
10 \text { indicates very good) }\end{array}$} & 1-All & 56 & 6.55 & 1.19 & \\
\hline & 2-Low EI & 18 & 6.72 & 0.89 & \\
\hline & 2-Mid EI & 14 & 6.71 & 0.91 & \\
\hline & 2-High EI & 22 & 6.73 & 1.35 & \\
\hline & 2-All & 54 & 6.72 & 1.09 & \\
\hline & 3-Low EI & 18 & 7.56 & 0.70 & \\
\hline & 3-Mid EI & 14 & 7.29 & 1.14 & \\
\hline & 3-High EI & 29 & 7.41 & 0.95 & \\
\hline & 3-All & 61 & 7.43 & 0.92 & \\
\hline & Total & 171 & 6.92 & 1.13 & \\
\hline & Levene s & mog & of var & 4 (p-value & \\
\hline
\end{tabular}

${ }^{1}$ The scores obtained for EI level were classified into three groups (low, mid or high) according to their percentile ranks. $* * *$ Significant at $0.01 \quad * *$ Significant at $0.05 \quad *$ Significant at 0.10

As for PROFIT judgments, we note that loan officers with a low level of EI gave PROFIT an average of rating of 6.57 (standard deviation $=1.35)$, those with mid EI, an average rating of 6.96 (standard deviation $=1.32$ ), and those with high EI, an average rating of 7.04 (standard deviation = 1.44). ANOVA results (Table IV, Panel A) fail to show any 
significant differences in a comparison of the three groups $(\mathrm{p}=0.156)$. EI level therefore does not influence judgments about PROFIT. The F-Test (Table IV, Panel B) does not indicate an interaction effect between EI level and PROFIT judgment, regardless of disclosure method $(\mathrm{p}=0.629)$.

Therefore, the impact of the method used to disclose contingencies on judgments about PROFIT is not affected by loan officers' EI level. H2 is not supported.

TABLE IV: IMPACT OF THE CHARACTERISTICS OF INFORMATION DISCLOSURE ON PROFITABILITY POTENTIAL JUDGMENT USING THE EI MODERATING

\begin{tabular}{|c|c|c|c|c|c|}
\hline \multicolumn{6}{|c|}{ VARIABLE } \\
\hline & EI Level $^{1}$ & $\mathrm{~N}$ & Mean & Std Dev. & $\mathrm{F}$ \\
\hline \multicolumn{5}{|l|}{ Panel A: Impact of EI Level on Profitability } & (p-value) \\
\hline Potential(PROFIT) & Low & 54 & 6.57 & 1.35 & \\
\hline \multirow{2}{*}{$\begin{array}{l}\text { I believe ABC's ability to sustain future profit growth is } \\
\text {. (on a 10-point Likert scale where } 1\end{array}$} & High & 71 & 7.04 & 1.44 & $(0.156)$ \\
\hline & Total & 171 & 6.87 & 1.39 & \\
\hline
\end{tabular}

indicates very poor and 10 indicates very good)

Levene statistic for homogeneity of variance $=0.294(\mathrm{p}$-value $=0.746)$

\begin{tabular}{|c|c|c|c|c|c|}
\hline \multirow[t]{2}{*}{ Panel B: Profitability Potential (PROFIT) } & $\begin{array}{l}\text { Group and } \\
\text { EI level }^{1}\end{array}$ & $\mathrm{~N}$ & Mean & Std Dev. & $\begin{array}{l}\text { F } \\
\text { (p-value) }\end{array}$ \\
\hline & 1-Low EI & 18 & 6.00 & 1.33 & \\
\hline I believe ABC's ability to sustain future profit growth is & 1-Mid EI & 18 & 6.50 & 1.72 & 0.648 \\
\hline _. (on a 10-point Likert scale where 1 indicates & 1-High EI & 20 & 6.60 & 1.60 & $(0.629)$ \\
\hline \multirow[t]{10}{*}{ very poor and 10 indicates very good) } & 1-All & 56 & 6.38 & 1.56 & \\
\hline & 2-Low EI & 18 & 6.44 & 1.04 & \\
\hline & 2-Mid EI & 14 & 7.29 & 0.61 & \\
\hline & 2-High EI & 22 & 7.18 & 1.53 & \\
\hline & 2-All & 54 & 6.96 & 1.23 & \\
\hline & 3-Low EI & 18 & 7.28 & 1.41 & \\
\hline & 3-Mid EI & 14 & 7.21 & 1.21 & \\
\hline & 3-High EI & 29 & 7.24 & 1.21 & \\
\hline & 3-All & 61 & 7.25 & 1.23 & \\
\hline & Total & 171 & 6.87 & 1.39 & \\
\hline
\end{tabular}

\footnotetext{
${ }^{1}$ The scores obtained for EI level were classified into three groups (low, mid or high) according to their percentile ranks.$$
* * * \text { Significant at } 0.01 \quad * * \text { Significant at } 0.05 \quad * \text { Significant at } 0.10
$$

TABLE V: IMPACT OF THE CHARACTERISTICS OF INFORMATION DISCLOSURE ON JUDGMENTS ABout AbiLity to PAy DebTS USING THE EI MODERATING VARIABLE

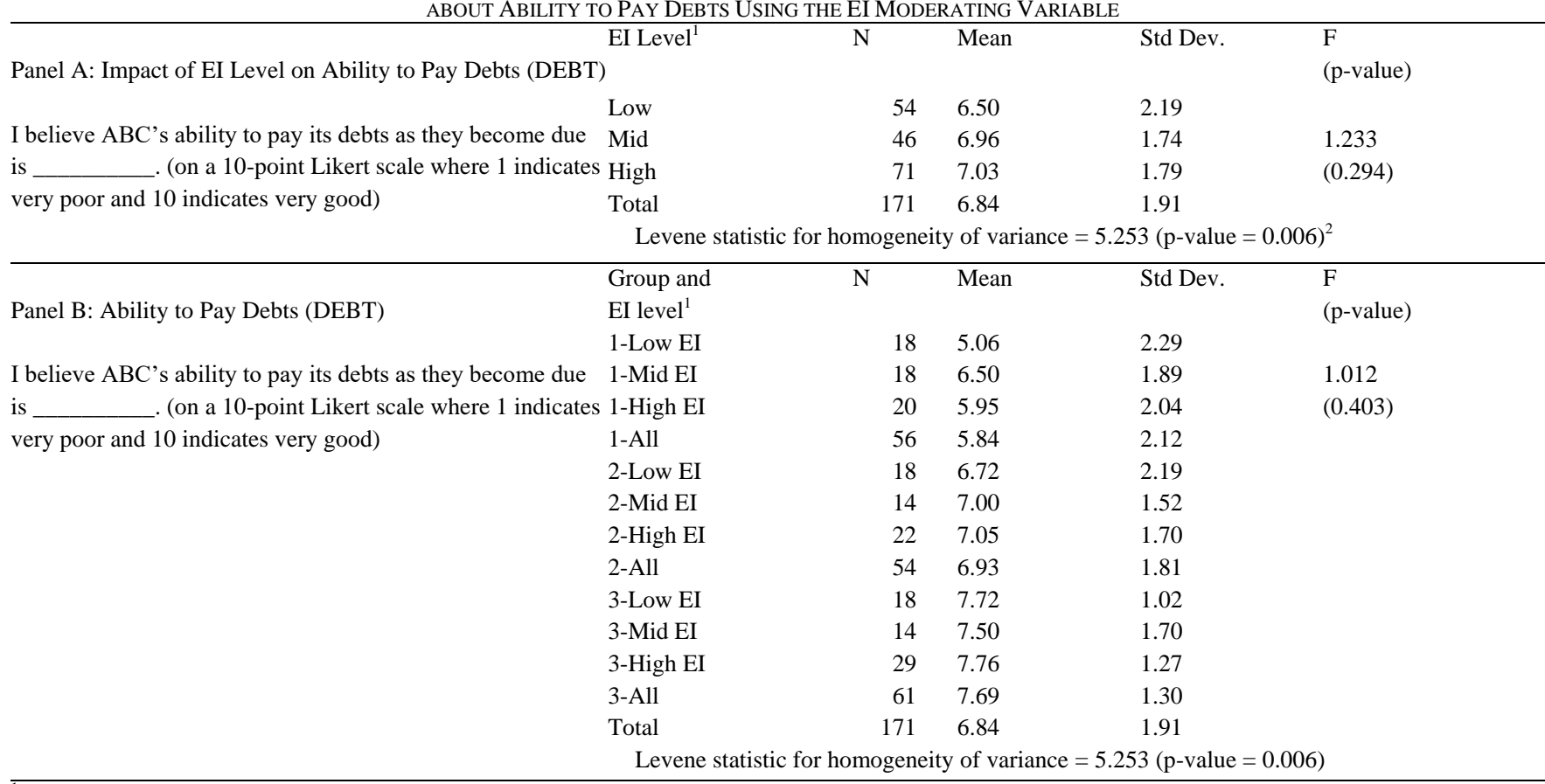

\footnotetext{
${ }^{1}$ The scores obtained for EI level were classified into three groups (low, mid or high) according to their percentile ranks.

${ }^{2}$ Analysis of variance (ANOVA) was valid even without homogeneity of variance (Levene test $=0.006$ ) considering that the data were normally distributed relative to the dependent variable, the sample was large, the experimental groups were equivalent in terms of their respondents and two factors were used (DEBT judgment and EI).

$$
\text { *** Significant at } 0.01 \quad * * \text { Significant at } 0.05 \quad * \text { Significant at } 0.10
$$
}

Concerning DEBT judgment, loan officers with low EI awarded an average rating of 6.50 (standard deviation =
2.19), while those with mid and high EI gave average ratings of 6.96 (standard deviation $=1.74$ ) and 7.03 
( standard deviation $=1.79)$ respectively. ANOVA results (Table V, Panel A) indicate no significant differences in a comparison of the three groups $(p=0.294)$. Thus, EI level does not affect DEBT judgments. Based on the F-test (Table $\mathrm{V}$, Panel B), we cannot conclude that an interaction effect exists; in other words, EI level has no effect on DEBT judgment regardless of the method used to disclose the information $(\mathrm{p}=0.403)$. Hence, the impact of the method for disclosing contingencies on judgments about DEBT is not influenced by loan officers' EI level. H3 is therefore not supported.

Concerning GROWTH judgment, loan officers with low EI awarded an average rating of 6.54 (standard deviation $=$
1.31), while those with mid and high EI gave average ratings of 6.65 (standard deviation $=1.32$ ) and 6.77 (standard deviation $=1.15)$ respectively. ANOVA results (Table VI, Panel A) indicate no significant differences in a comparison of the three groups $(p=0.574)$. Thus, EI level does not affect GROWTH judgments. Based on the F-test (Table VI, Panel B), we cannot conclude that an interaction effect exists; in other words, EI level has no effect on GROWTH judgment regardless of the method used to disclose the information $(\mathrm{p}=0.237)$. Hence, the impact of the method for disclosing contingencies on judgments about GROWTH is not influenced by loan officers' EI level. H4 is therefore not supported.

TABLE VI: IMPACT OF THE CHARACTERISTICS OF INFORMATION DISCLOSURE ON JUDGMENTS ABOUT ABILITY TO SUSTAIN GROWTH USING THE EI MODERATING VARIABLE

\begin{tabular}{|c|c|c|c|c|c|}
\hline \multirow{3}{*}{$\begin{array}{l}\text { Panel A: Impact of EI Level on Ability to Sustain Growth } \\
\text { (GROWTH) }\end{array}$} & EI Level $^{1}$ & $\mathrm{~N}$ & Mean & Std Dev. & $\begin{array}{l}\text { F } \\
\text { (p-value) }\end{array}$ \\
\hline & Low & 54 & 6.54 & 1.31 & \\
\hline & Mid & 46 & 6.65 & 1.32 & 0.557 \\
\hline \multirow{2}{*}{$\begin{array}{l}\text { I believe ABC's growth potential is } \\
\text { point Likert scale where } 1 \text { indicates very poor and } 10\end{array}$} & High & 71 & 6.77 & 1.15 & $(0.574)$ \\
\hline & Total & 171 & 6.67 & 1.25 & \\
\hline
\end{tabular}
indicates very good)

Levene statistic for homogeneity of variance $=1.601(\mathrm{p}$-value $=0.205)$

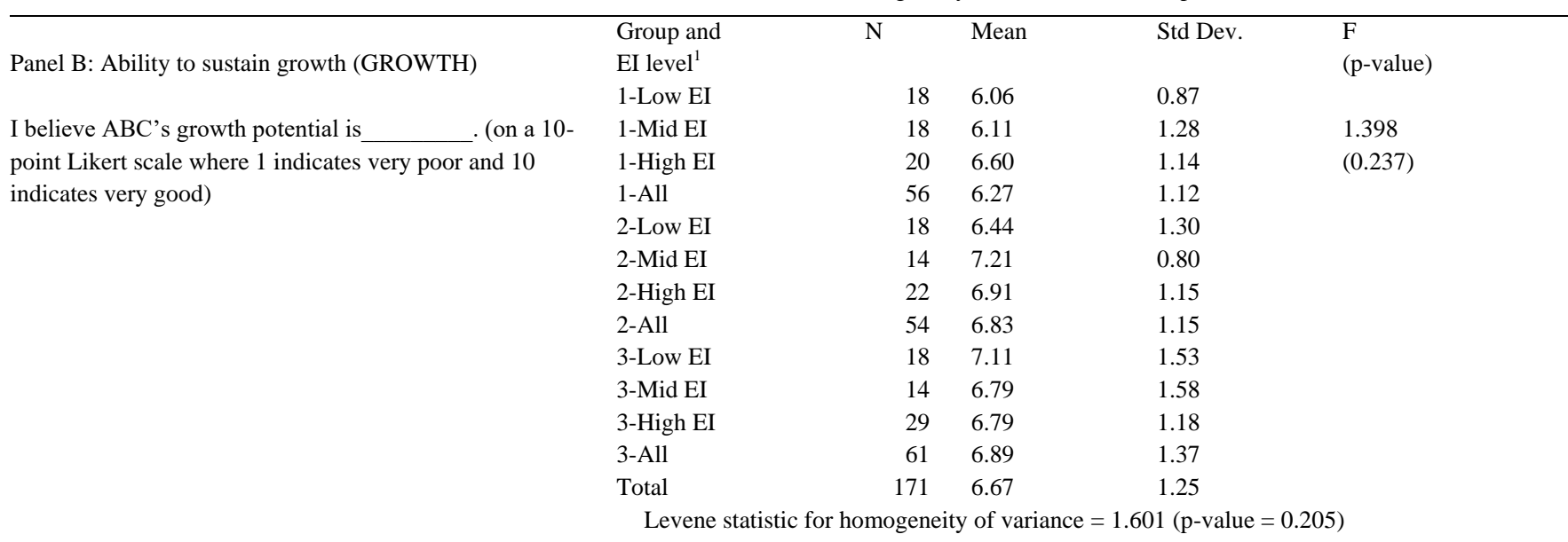

\footnotetext{
${ }^{1}$ The scores obtained for EI level were classified into three groups (low, mid or high) according to their percentile ranks.

*** Significant at $0.01 \quad * *$ Significant at $0.05 \quad *$ Significant at 0.10
}

TABLE VII: REGRESSION ON THE DECISION TO GRANT THE LOAN ${ }^{4}$ Logistic Regression using CONDITION ${ }^{1}$ Judgment and $\mathrm{EI}^{2}$ Probability $\left(\right.$ Decision $_{\mathrm{i}}=$ yes $)=\beta_{0}+\beta_{1}\left(\mathrm{CONDITION}_{\mathrm{i}}\right)+\beta_{2}\left(\mathrm{EI}_{\mathrm{i}}\right)+\varepsilon_{\mathrm{i}}$

$\begin{array}{llll}\text { Variable } & \text { Expectation } & \text { Coefficient } & \text { p-value } \\ \text { Intercept } & & -0.154 & \\ \text { CONDITION } & - & 2.323 & 0.002^{*} * * 3 \\ \text { EI } & & & 0.556^{3} \\ \text { EI x CONDITION } & & & 0.198^{3}\end{array}$

\footnotetext{
Test for $\beta_{1}$ to $\beta_{2}=0 \quad$ Chi-square $=24.708 p<0.001$

Hosmer and Lemeshow Chi-square $=0.000 \quad p=1.000$

Classification $=79.9 \%$
}

\footnotetext{
${ }^{1}$ Overall financial condition judgment (on a 10-point Likert scale where 1 indicates very poor and 10 indicates very good).

${ }^{2}$ The global EI score is used for this regression.

${ }^{3}$ One-tailed p-value.

${ }^{4}$ The decision to grant the loan is measured by Yes (1) or No (0).

*** Significant at $0.01 \quad * *$ Significant at $0.05 *$ Significant at 0.10
}

Table VII presents the logistic regression on the loan granting decision with CONDITION as the independent variable. According to the statistical results, EI levels represented by overall score do not help explain the loan granting decision $(\mathrm{p}=0.556)$. In addition, the results are not strong enough to conclude that an interaction effect exists between CONDITION judgment and EI level ( $p=0.198)$. EI therefore has no effect on the loan granting decision regardless of CONDITION group. Thus, the impact of CONDITION judgment on the loan granting decision is not influenced by EI level. H5 is therefore not supported.

Table VIII presents the logistic regression on the loan granting decision with PROFIT as the independent variable. Results indicate that EI level represented by overall score does not help explain the loan granting decision $(p=0.328)$. However, we observe that the results are significant enough to support the presence of an interaction effect between PROFIT judgment and EI level $(\mathrm{p}=0.066)$. Therefore, the impact of PROFIT judgment on the loan granting decision is marginally influenced by the loan officers' EI level. H6 is therefore marginally supported.

Table IX presents the logistic regression on the loan 
granting decision with DEBT as the independent variable. According to the statistical results, EI levels represented by overall score do not help explain the loan granting decision $(\mathrm{p}=0.575)$. In addition, the results are not strong enough to conclude that an interaction effect exists between DEBT judgment and EI level $(\mathrm{p}=0.676)$. EI therefore has no effect on the loan granting decision regardless of DEBT group. Thus, the impact of DEBT judgment on the loan granting decision is not influenced by EI level. $\mathrm{H} 7$ is therefore not supported.

\begin{tabular}{|c|c|c|c|}
\hline \multicolumn{4}{|c|}{$\frac{\text { TABLE VIII: REGRESSION ON THE DECISION TO GRANT THE LOAN }}{4}$} \\
\hline \multicolumn{4}{|c|}{ Probability $\left(\right.$ Decision $_{\mathrm{i}}=$ yes $)=\beta_{0}+\beta_{1}\left(\right.$ PROFIT $\left._{\mathrm{i}}\right)+\beta_{2}\left(\mathrm{EI}_{\mathrm{i}}\right)+\varepsilon_{\mathrm{i}}$} \\
\hline Variable & \multirow[t]{2}{*}{ Expectatio } & on Coefficient & p-value \\
\hline Intercept & & 0.223 & cos \\
\hline PROFIT & - & 2.112 & $0.006 * * * 3$ \\
\hline EI & & \multicolumn{2}{|r|}{$0.328^{3}$} \\
\hline EI x PROI & & \multicolumn{2}{|r|}{$0.066^{3} *$} \\
\hline \multicolumn{2}{|c|}{ Test for $\beta 1$ to $\beta 2=0$} & \multicolumn{2}{|c|}{ Chi-square $=17.104 \mathrm{p}=0.004$} \\
\hline \multicolumn{4}{|c|}{ Hosmer and Lemeshow } \\
\hline \multicolumn{4}{|c|}{ Classification $=78.6 \%$} \\
\hline \multirow{5}{*}{\multicolumn{4}{|c|}{$\begin{array}{l}{ }^{1} \text { Profitability potential judgment (on a } 10 \text {-point Likert scale where } 1 \\
\text { indicates very poor and } 10 \text { indicates very good). } \\
{ }^{2} \text { The global EI score is used for this regression. } \\
{ }^{3} \text { One-tailed p-value. } \\
{ }^{4} \text { The decision to grant the loan is measured by Yes }(1) \text { or No }(0) \text {. } \\
* * * \text { Significant at } 0.01 \quad * * \text { Significant at } 0.05 \quad * \text { Significant at } 0.10\end{array}$}} \\
\hline & & & \\
\hline & & & \\
\hline & & & \\
\hline & & & \\
\hline \multicolumn{4}{|c|}{ TABLE IX: REGRESSION ON THE DECISION TO GRANT THE LOAN ${ }^{4}$} \\
\hline \multicolumn{4}{|c|}{ Logistic Regression using DEBT ${ }^{1}$ Judgment and $\mathrm{EI}^{2}$} \\
\hline \multicolumn{4}{|c|}{ Probability $\left(\right.$ Decision $_{\mathrm{i}}=$ yes $)=\beta_{0}+\beta_{1}\left(\mathrm{DEBT}_{\mathrm{i}}\right)+\beta_{2}\left(\mathrm{EI}_{\mathrm{i}}\right)+\varepsilon_{\mathrm{i}}$} \\
\hline Variable & \multirow[t]{2}{*}{ Expectation } & Coefficient & \multirow[t]{2}{*}{ p-value } \\
\hline Intercept & & -0.470 & \\
\hline DEBT & \multirow[t]{3}{*}{-} & \multirow[t]{3}{*}{2.955} & $0.000 * * *^{3}$ \\
\hline EI & & & $0.575^{3}$ \\
\hline EI x DEB & & & $0.676^{3}$ \\
\hline
\end{tabular}

Test for $\beta 1$ to $\beta 2=0 \quad$ Chi-square $=42.643 \mathrm{p}<0.001$

Hosmer and Lemeshow Chi-square $=0.000 \quad \mathrm{p}=1.000$

Classification $=82.4 \%$

${ }^{1}$ Judgment about ability to pay debts (on a 10-point Likert scale where 1 indicates very poor and 10 indicates very good)

${ }^{2}$ The global EI score is used for this regression.

${ }^{3}$ One-tailed p-value.

${ }^{4}$ The decision to grant the loan is measured by Yes (1) or No (0).

*** Significant at $0.01 \quad * *$ Significant at $0.05 *$ Significant at 0.10

Table $\mathrm{X}$ presents the logistic regression on the loan granting decision with GROWTH as the independent variable. Results indicate that EI level represented by overall score does not help explain the loan granting decision $(\mathrm{p}=$ 0.515). However, we observe that the results are significant enough to support the presence of an interaction effect between GROWTH judgment and EI level ( $p=0.087$ ). Therefore, the impact of GROWTH judgment on the loan granting decision is marginally influenced by the loan officers' EI level. H8 is therefore marginally supported.

In terms of the relationship between intermediate judgments and the decision on the rate, the statistical results (Table XI, Panel A) indicate that EI levels, represented by overall score, do not help explain the interest rate decision. For each judgment, we observed CONDITION ( $\mathrm{p}=0.860)$;
PROFIT ( $\mathrm{p}=0.951)$; DEBT $(\mathrm{p}=0.632)$, and GROWTH ( $\mathrm{p}$ $=0.814)$. The F-test (Table XI, Panel B) is not conclusive regarding an interaction effect, i.e. EI level does not affect the interest rate decision, regardless of CONDITION judgment $(\mathrm{p}=0.801)$, PROFIT judgment $(\mathrm{p}=0.950)$, DEBT judgment $(\mathrm{p}=0.835)$, and GROWTH judgment $(\mathrm{p}=0.777)$. Therefore, the impact of intermediate judgments on the interest rate decision is not influenced by loan officers' EI level. H9, H10, H11 and H12 are not supported.

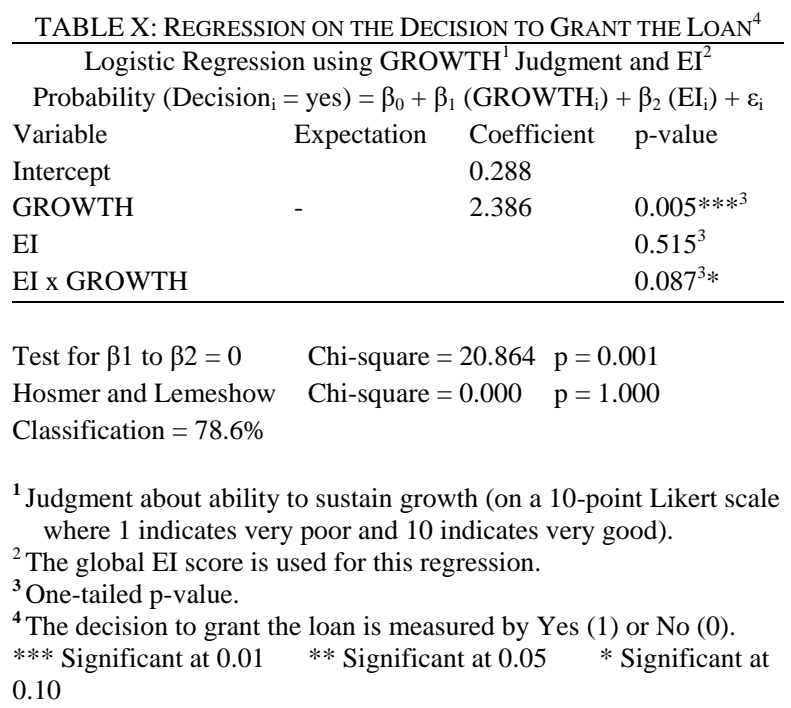

TABLE XI: IMPACT OF INTERMEDIATE JUDGMENTS ON THE INTEREST RATE PREMIUM DECISION USING THE EI ${ }^{1}$ MODERATING VARIABLE

\begin{tabular}{llll}
\hline & Intermediate & $F$ & p-value \\
Panel A: Interest Rate Premium & Judgments & & \\
EI Level Impact & & & \\
Please indicate the appropriate rate you & CONDITION & 0.151 & 0.860 \\
would ask for the loan requested, & PROFIT & 0.050 & 0.951 \\
considering that the repayment of & DEBT & 0.459 & 0.632 \\
principal is a fixed monthly installment & GROWTH & 0.206 & 0.814
\end{tabular}
and the interest is variable and calculated on the basis of the premium added to the preferential rate in effect at your institution (whether or not you recommend the loan).

\begin{tabular}{|c|c|c|c|}
\hline $\begin{array}{l}\text { Panel B: Interest Rate Premium } \\
\text { Interaction Effect Between Intermediate } \\
\text { judgments and EI Level }\end{array}$ & $\begin{array}{l}\text { Intermediate } \\
\text { Judgments }\end{array}$ & $\mathrm{F}$ & p-value \\
\hline $\begin{array}{l}\text { Please indicate the appropriate rate you } \\
\text { would ask for the loan requested, } \\
\text { considering that the repayment of } \\
\text { principal is a fixed monthly installment } \\
\text { and the interest is variable and calculated } \\
\text { on the basis of the premium added to the } \\
\text { preferential rate in effect at your } \\
\text { institution (whether or not you } \\
\text { recommend the loan). }\end{array}$ & $\begin{array}{l}\text { CONDITION } \\
\text { PROFIT } \\
\text { DEBT } \\
\text { GROWTH }\end{array}$ & $\begin{array}{l}0.222 \\
0.052 \\
0.181 \\
0.253\end{array}$ & $\begin{array}{l}0.801 \\
0.950 \\
0.835 \\
0.777\end{array}$ \\
\hline
\end{tabular}

\section{CONCLUSION}

The conclusions of [1] and the relevant psychology literature support the notion that emotions and their management can influence decision making. The decision process of loan officers has become more complex because of greater uncertainty and instability in financial and business environments. According to the literature, the judgments and decisions of professional financial statement 
users, including loan officers, can be influenced by some factors despite the users' level of professional sophistication.

Based on [1], casting EI as a moderating variable in the relationship between the method of disclosing contingencies and main judgments, and between these judgments and loan granting or interest rate decisions, did not establish that loan officers' EI has a significant moderating effect on these relationships. This may be because institutional oversight and directives are sufficiently clear and accurate and that they provide guidance and minimize loan officers' personal differences in terms of EI. Thus, the goal of the current study was to determine whether EI acts as a moderating variable in loan officers' information processing and to assess EI's potential moderating impacts on risk perception and credit decisions within loan officers' intermediate judgment process.

To make a main judgment about overall risk and the overall risk trend, the loan officer must first reflect and form an opinion about several factors such as the enterprise's overall situation, including financial situation, profitability, and growth potential. Although institutional policies guide main judgments (about ORR and OTR), they make no stipulations about the other factors we have discussed, making this step of decision making an unstructured process that gives loan officers considerable latitude to form their own opinions. For this reason, and to round out the study by [1], we found it relevant to study the moderating impact of EI on loan officers' intermediate judgments, defined as the process that looks at the foregoing four factors.

We show that EI as a moderating variable in the relationship between the method of disclosing contingencies and intermediate judgments, and between these judgments and loan granting or interest rate decisions, does not have a significant effect on these relationships, except between two intermediate judgments (profitability potential and ability to sustain growth) and the loan granting decision, for which results were marginally significant. These latter results confirm partially the conclusion of [1] that loan officers follow the standards of their institution to make their main judgments on the ORR and OTR, and that these standards provide guidance and have the effect of minimizing their personal differences in terms of EI. Conversely, during the intermediate judgment stage, loan officers have much more freedom to make their own opinions.

Concerning our non-significant results, our findings potentially confirm the limitations stated by [1] about the tool used. Accordingly, the TEIQue was unable to capture the differences between subjects. The low variability in EI scores did not allow us to observe differences on the basis of low and high EI score. In addition, the cut-off scores between low, mid, and high scores, based on percentile ranks, did not represent reality. Trait EI is a constellation of emotion-related personality traits capturing a wide variety of emotions; however, anxiety is likely the main emotion involved in loan officers' decision making. Thus, the TEIQue is probably not precise enough in its assessment to provide information about the management of anxiety.

However, for all relationships, and without considering EI, we observed that the method of disclosing information on contingencies influenced all intermediate judgments, and these judgments influenced the loan granting and interest rate decisions. This suggests that participants may have functionally fixated on the revenue listed in the income statement, in line with [50], who concluded that functional fixation is not automatically eliminated by accounting knowledge or experience. Consistent with [1], we conclude that participants with higher levels of EI were not able to overcome the effects of their functional fixation, and that their EI, as conceptualized and measured in this study, was not a moderating factor in the relationships between the variables pertaining to the loan officers' decision process.

This study is not without limitations. First, the experimental design was built around a fictitious case, whereas the experimental context should challenge loan officers' emotional skills. Second, the TEIQue is probably not precise enough in its assessment to provide information about the management of anxiety. Future research could use other EI measures with greater sensitivity in capturing individual differences.

This study rounds out the work of [1] by demonstrating that loan officers' main judgments are guided by their institutions' standards, whereas their intermediate judgments enjoy (marginally) more flexibility. However, results also show that the TEIQue is not an appropriate tool for studying the impact of loan officers' EI because results were barely significant, even in regard to judgments not circumscribed by the loan officers' institutions.

\section{CONFLICT OF INTEREST}

The authors declare no conflict of interest.

\section{AUTHOR CONTRIBUTIONS}

Lagrange and Viger planned the research; Lagrange conducted the research; Lagrange, Viger and Morin analyzed the data; Lagrange wrote the paper; all authors had approved the final version.

\section{REFERENCES}

[1] B. Lagrange, C. Viger, and E. E. Morin, "The moderating effect of emotional intelligence on loan officers' judgments and decisions," Journal of Business and Management, vol. 23, no. 1/2, 2017.

[2] W. F. Treacy and S. M. Carey, "Credit risk rating at large US banks," Federal Reserve Bulletin, vol. 84, no. 11, pp. 897-921, 1998.

[3] V. Bruns, D. V. Holland, D. A. Shepherd, and J. Wiklund, "The role of human capital in loan officers' decision policies," Entrepreneurship: Theory and Practice, vol. 32, no. 3, pp. 485-506, 2008.

[4] A. N. Berger and G. G. Udell, "Small business and debt finance," in Handbook of Entrepreneurship Research, Z. J. Acs and D. B. Audretsch, Eds. Boston: Kluwer, 2003, pp. 299-328.

[5] C. Zopounidis and M. Doumpos, "Multi-criteria decision aid in financial decision making: Methodologies and literature review," Journal of Multi-Criteria Decision Analysis, vol. 11, no. 4-5, pp. 167$186,2002$.

[6] W. Rodgers and L. W. Johnson, "Integrating credit models using accounting information with," Accounting and Finance, vol. 28, no. 2 , pp. 1-22, 1988.

[7] D. Deakins and G. Hussain, Risk Assessment by Bank Managers, Birmingham: University of Central England, 1994.

[8] F. Wilson, S. Carter, S. Tagg, E. Shaw, and W. Lam, "Bank loan officers' perceptions of business owners: The role of gender," British Journal of Management, vol. 18, no. 2, pp. 154-171, 2007.

[9] Desjardins, offres d'emploi. Mouvement desjardins. [Online] Available:

https://desjardins.taleo.net/careersection/dcom/moresearch.ftl?lang=fr

[10] B. Lagrange, C. Viger, and A. Anandarajan, "Contingency liabilities: The effect of three alternative reporting styles," Research in Accounting Regulation, vol. 27, no. 2, pp. 119-128, 2015. 
[11] C. Viger, R. Belzile, and A. Anandarajan, "Disclosure versus recognition of stock option compensation: Effect on the credit decisions of loan officers," Behavioral Research in Accounting, vol. 20, no. 1, pp. 93-113, 2008

[12] R. Belzile, A. Fortin, and C. Viger, "Recognition versus disclosure of stock option compensation: An analysis of judgments and decisions of nonprofessional investors," Canadian Academic Accounting Association, vol. 5, no. 2, pp. 147-179, 2006.

[13] C. Viger, A. Anandarajan, A. P. Curatola, and W. Ben-Amar, "Behavioral implications of alternative going concern reporting formats," Advances in Accounting Behavioral Research, vol. 7, pp. 51-71, 2004.

[14] D. E. Hirst, P. E. Hopkins, and J. M. Wahlen, "Fair values, income measurement, and bank analysts' risk and valuation judgments," Accounting Review, vol. 79, no. 2, pp. 454-472, 2004.

[15] A. Anandarajan, C. Viger, and A. P. Curatola, "An experimental investigation of alternative going-concern reporting formats: A Canadian experience," Canadian Accounting Perspectives, vol. 1, no. 2, pp. 141-162, 2002.

[16] L. A. Maines and L. S. McDaniel, "Effects of comprehensive-income characteristics on nonprofessional investors' judgments: The role of financial-statement presentation format," Accounting Review, vol. 75, no. 2, pp. 179-207, 2000.

[17] P. E. Hopkins, R. W. Houston, and M. F. Peters, "Purchase, pooling, and equity analysts' valuation judgments," Accounting Review, vol. 75 , no. 3, pp. 257-281, 2000.

[18] D. E. Hirst and P. E. Hopkins, "Comprehensive income reporting and analysts' valuation judgments," Journal of Accounting Research, vol 36, no 3, pp. 47-75, 1998

[19] D. Hirshleifer and S. H. Teoh, "Limited attention, information disclosure, and financial reporting," Journal of Accounting and Economics, vol. 36, no. 1-3, p. 337, 2003.

[20] D. Keltner and E. J. Horberg, "Emotion-cognition interactions," $A P A$ Handbook of Personality and Social Psychology, vol. 1, pp. 623-664, 2015.

[21] J. Kounios and M. Beeman, "The cognitive neuroscience of insight," Annual Review of Psychology, vol. 65, no. 1, pp. 71-93, 2014

[22] C. F. Camerer, "Strategizing in the brain," Science, vol. 300, pp. 1673-1675, 2003.

[23] H. S. Simon, Administrative Behavior: A Study of the DecisionMaking Processes in Administrative Organizations, New York: Free Press, 1947.

[24] V. Chanut, N. Guibert, J. Rojot, and P. L. Dubois, "Les limites de la rationalité limitée? Un essai de réflexion en sciences de gestion (French)," Management \& Avenir, vol. 8, no. 48, p. 300, 2011.

[25] S. Jarboui and Y. Boujelbene, "The behavioral approach and the rationality of economic decisions: Application to banks managers," Global Business and Management Research: An International Journal, vol. 4, no. 2, pp. 205-219, 2012.

[26] P. Greenwich. (2005). Behavioural finance definitions: Main concepts. [Online]. Available: http://perso.wanadoo.fr/greenwich/bfdef.htm

[27] A. R. Damasio, Descartes' Error: Emotion, Reason and the Human Brain, New York: Penguin Putnam, 1994.

[28] G. L. Clore and K. Gasper, "Feeling is believing: Some affective influences on belief," in Emotions and Beliefs: How Feelings Influence Thoughts, N. Frijda, T. Manstead, and S. Bem, Eds. Cambridge, England: Cambridge University Press, 2000, pp. 10-44.

[29] B. L. Fredrickson, "What good are positive emotions?" Review of General Psychology, vol. 2, no. 3, pp. 300-319, 1998

[30] K. V. Petrides and A. Furnham, "Trait emotional intelligence: Psychometric investigation with reference to established trait taxonomies," European Journal of Personality, vol. 15, no. 6, pp. 425-448, 2001.

[31] M. Mikolajczak, "Going beyond the ability-trait debate: The three level model of emotional intelligence," Electronic Journal of Applied Psychology, vol. 5, no. 2, pp. 25-31, 2009.

[32] C. K. Fallon, A. R. Panganiban, R. Wohleber, G. Matthews, A. M. Kustubayeva, and R. Roberts, "Emotional intelligence, cognitive ability and information search in tactical decision-making," Personality and Individual Differences, vol. 65, pp. 24-29, 2014

[33] G. J. Browne and M. G. Pitts, "Stopping rule use during information search in design problems," Organizational Behavior and Human Decision Processes, vol. 95, no.2, pp. 208-224, 2004.

[34] D. Ansiau, C. Dejoux, I. Dherment-Ferer, H. Wechtler, and L. Bergery, "Intelligence émotionnelle et processus de décision (French)," Gestion 2000, vol. 28, no. 3, pp. 67-81, 2011 .

[35] N. T. Telle, C. Senior, and M. Butler, "Trait emotional intelligence facilitates responses to a social gambling task," Personality and Individual Differences, vol. 50, no. 4, pp. 523-526, 2011.
[36] K. Gasper and G. L. Clore, "Do you have to pay attention to your feelings to be influenced by them?" Personality and Social Psychology, vol. 26, no. 6, pp. 698-711, 2000.

[37] E. J. Johnson and A. Tversky, "Affect, generalization and the perception of risk," Journal of Personality and Social Psychology, vol. 45 , no. 1 , pp. 20-31, 1983.

[38] M. G. Seo and L. F. Barrett, "Being emotional during decisionmaking: Good or bad? An empirical investigation," Academy of Management Journal, vol. 50, no. 4, 923-940, 2007.

[39] R. N. Sullivan, "Deploying financial emotional intelligence," Financial Analysts Journal, vol. 67, no. 6, pp. 4-10, 2011

[40] C. M. Kuhnen and B. Knutson, "The influence of affect on beliefs, preferences, and financial decisions," Journal of Financial and Quantitative Analysis, vol. 46, no. 3, pp. 605-626, 2011.

[41] M. Nussbaum, Upheavals of Thought: The Intelligence of Emotions, New York, NY: Cambridge University Press, 2001

[42] P. Winkielman, R. B. Zajonc, and N. Schwarz, "Subliminal affective priming resists attributional interventions," Cognition and Emotion vol. 11, pp. 433-465, 1997

[43] J. A. Lambie, "On the irrationality of emotion and the rationality of awareness," Consciousness and Cognition, vol. 17, no. 3, pp. 946-980, 2007.

[44] E. M. Morin, C. Aubé, and K. J. Johnson, Psychologie et Management (in French), Montréal: Chenelière Éducation, 2015.

[45] M. Mikolajczak, E. Ray, O. Luminet, C. Fillee, and P. De Timary, "The moderating impact of emotional intelligence on free cortisol responses to stress," Psychoneuroendocrinology, vol. 32, no. 8, pp. 1000-1012, 2007.

[46] E. J. Austin, D. Farrelly, C. Black, and H. Moore, "Emotional intelligence, Machiavellianism and emotional manipulation: Does EI have a dark side?" Personality and Individual Differences, vol. 43, pp. 179-189, 2007

[47] T. Chamorro-Premuzic, E. Bennett, and A. Furnham, "The happy personality: Mediational role of trait emotional intelligence," Personality and Individual Differences, vol. 42, pp. 1633-1639, 2007.

[48] N. Sevdalis, K. Petrides, and N. Harvey, "Trait emotional intelligence and decision-related emotions," Personality and Individual Differences, vol. 42, pp. 1347-1358, 2007.

[49] K. V. Petrides, R. Pita, and F. Kokkinaki, "The location of trai emotional intelligence in personality factor space," British Journal of Psychology, vol. 98, no. 2, pp. 273-289, 2007.

[50] D. T. Dearman and M. D. Shields, "Avoiding accounting fixation: Determinants of cognitive adaptation to differences in accounting method," Contemporary Accounting Research, vol. 22, no. 2, pp. 351$384,2005$.

Copyright $\odot 2020$ by the authors. This is an open access article distributed under the Creative Commons Attribution License which permits unrestricted use, distribution, and reproduction in any medium, provided the original work is properly cited (CC BY 4.0).

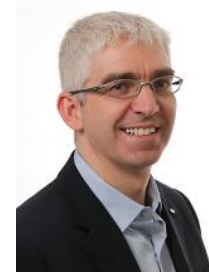

Bruce Lagrange is an associate professor at the Université du Québec à Rimouski (UQAR). He is a member of Ordre des comptables professionnels agréés du Québec. He joined UQAR in 2009 after acquiring substantial experience during his more than 10 years as a loan officer and director of credit approval for a major financial institution. He has indepth knowledge and a strong understanding of the credit rating process of North American banks.

He has taught several classes (cost and decision making, management accounting, intermediate and advanced financial accounting and organizational performance) at the undergraduate and graduate levels.

His main research interests concern the usefulness of financial information for decision-making, and more specifically, the impacts of financial information and personal factors on financial users' judgments and decisions. $\mathrm{He}$ is also a researcher associated with the Chair on Cooperation Guy Bernier, affiliated with the School of Business at the Université du Québec à Montreal.

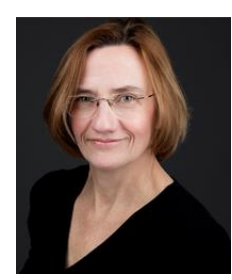

Chantal Viger is a full professor at the Université du Québec à Montréal (Canada). She is a member of the Ordre des comptables professionnels agréés du Québec. She has extensive professional experience conducting experimental research and has published in several academic journals (Behavioral Research in Accounting, Advances in Behavioral Accounting Research, Canadian Accounting Perspectives, Comptabilité-Contrôle-Audit 
Management Accounting, Journal of Cost Management and Research in Accounting Regulation).

She has taught advanced financial accounting courses at the bachelor's level and methodology courses at the master's and Ph.D. levels. She gives doctoral-level accounting seminars on the communication paradigm and the use of experimental methodology in accounting research.

Her main research interest is to determine whether the presentation format of financial accounting information affects the perceptions, judgments and decisions of professional and non-professional financial statement users. She also conducts studies linking accounting and education, including recent investigations of the factors (including alternative teaching methods such as distance learning) that explain the success of undergraduate accounting students. Her work has been published in Accounting Education, Journal of Further and Higher Education as well as in Accounting Education: An international journal.

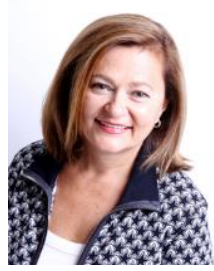

Estelle M. Morin is a psychologist and full professor in the Department of Management, HEC Montréal. Professor Morin has devoted her career to the promotion of mental health at work, employee engagement and organizational performance. Her specialties include emotional intelligence, job design and work organization, work meaningfulness and quality of work life.

Professor Morin is a member of Ordre des psychologues du Québec (1984), the Canadian Psychological Association (1984), the American Psychological Association (1986) and the Consortium for Research on Emotional Intelligence in Organizations (1996).

Her main activities include teaching and action research in psychology applied to management and organizational development; executive education; conferences on emotional intelligence, mental health, psychological distress and well-being; quality of working life; meaning of work and work meaningfulness; and executive leadership and organizational effectiveness. 